\title{
Collection Development Based on Patron Requests: Collaboration between Interlibrary Loan and Acquisitions
}

\author{
by \\ Suzanne M. Ward \\ Head, Access Services, Purdue University Libraries \\ Tanner Wray \\ Head, Access Services, Memorial Library, University of \\ Wisconsin-Madison \\ Karl E. Debus-López \\ Chief Acquisitions Librarian, General Library System, \\ University of Wisconsin-Madison
}


Suzanne M. Ward is Head, Access Services, Purdue University Libraries. She holds a B.A. from UCLA, an A.M.L.S. from the University of Michigan, and an M.A. from Memphis State University. She can be reached at wardepurdue.edu. [corresponding author]

Tanner Wray is Head, Access Services, Memorial Library, University of Wisconsin-Madison. He holds a S.B. from the Massachusetts Institute of Technology, and an M.L.S. from Syracuse University. He can be reached at twraydlibrary.wisc.edu.

Karl E. Debus-López is Chief Acquisitions Librarian, General Library System, University of WisconsinMadison. He holds a B.A. and M.R.P. from Cornell University, and an M.L.S. from the University of Maryland. He can be reached at debus@library.wisc.edu. 
Collection Development Based on Patron Requests: Collaboration between Interlibrary Loan and Acquisitions

ABSTRACT

Libraries are exploring new models of collaboration between interlibrary loan, collection development, and acquisitions. This paper presents two models in which libraries set aside acquisitions or other funds to purchase books requested by patrons through interlibrary loan processes. Workflows, scope criteria, and departmental relationships are described. The article reports on several aspects of the effectiveness of these models, such as turnaround time (comparable to traditional ILL loans), average cost per book $(\$ 37.00)$, and patron satisfaction (very high). The authors also address the subsequent circulation of titles and report on the bibliographers' analysis of the relevance of the titles to the collection of one of the libraries.

KEYWORDS: Interlibrary Loan; Acquisitions; Collection Development; Collaboration 
Collection Development Based on Patron Requests: Collaboration between Interlibrary Loan and Acquisitions

Genesis of On-Demand Interlibrary Loan Purchasing

In the traditional model of interlibrary lending, one library borrows a book from a second library to fill its patron's request. After a few weeks' use, the book is then returned to the supplying library. Even if the two libraries enjoy reciprocal lending privileges at no direct cost, each library incurs costs associated with staff time, supplies, shipping, equipment, network fees, and more. The most recent cost study conducted by the Association of Research Libraries in 1996 reported the average cost for all interlibrary loan (ILL) transactions at $\$ 27.83$ for its member research libraries. [1] The borrowing library typically incurs about two-thirds of these costs. 
Many ILL operations also include some provisions to acquire materials outside of the library-to-library borrowing arena. For example, dissertations might be purchased directly from Dissertation Express or reports of government-sponsored research from the National Technical Information Service (NTIS). If the materials are not available through normal lending channels, some libraries go further and purchase items from other universities' academic departments, trade associations, or publishers on an as-needed basis.

Purchasing items outside the traditional ILL workflow, especially from many one-time suppliers, can be very time-consuming (identifying the supplier; confirming costs; arranging pre-payments if necessary, etc.) and thus extremely cost-intensive. Each library has its own policies determining how far it will go to fill requests for materials unavailable through interlibrary loan; whether its patrons pay some or all of the costs associated with obtaining these materials; and determining whether some or all of the material thus acquired will be added to the library collection or given to the patron to keep.

In recent years, some libraries have also expanded the concept of using non-interlibrary loan 
suppliers to provide the occasional routine materials on a purchase basis. One example is buying selected mainstream titles that other libraries are unlikely to lend, such as very recently published books at the height of their popularity. Another example is checking to see if titles requested by faculty members are still in print and, if so, purchasing the item. In many libraries, these requests appear to be handled on an informal, ad hoc basis with little or no separate funding and tracking mechanisms in place. Usually once the purchase decision has been made, the request passes from ILL to acquisitions for subsequent fulfillment, usually on a rush basis. The patron is often unaware that the ILL request has been transformed into a purchase. [2]

It is a small step from the occasional purchase of ILL requests to a more formalized program to develop criteria and workflow to meet patrons' immediate and future needs by routinely purchasing selected loan requests.

What is On-Demand Collection Development? 
Over the past few years, a few libraries have tested the model of on-demand collection development. In this model, interlibrary loan or access services librarians, in collaboration with their libraries' bibliographers and collection development officers (CDOs), agree on guidelines that will drive the decision to purchase rather than to borrow a book requested through interlibrary loan. The CDO or other administrator designates funds specifically for this purpose. The ILL or acquisitions staff usually establishes systems to track the titles purchased for later analysis.

There are many local variations on the actual implementation of these purchasing programs. Differences include the amount of funding; the selection criteria; the degree of involvement by technical services in the pre- and post-order process; the evaluation criteria; and others.

Bucknell University was the first to report the details of an on-demand interlibrary loan/acquisitions partnership. [3] Bucknell's program, begun in 1990, involved ordering all ILL requests for in-print titles on a rush basis from vendors and publishers. Bucknell staff found that it was more cost effective to 
purchase rather than borrow items requested by patrons. They also found that materials bought, rather than borrowed, made it to the hands of their patrons faster than ILL, therefore increasing customer satisfaction. Subsequent circulation of these titles also tended to be higher than for firm order titles. The 1999 article detailing Bucknell's on-demand ILL/acquisitions program is the earliest in the literature. The current authors have published and will shortly publish several articles on various aspects of their institutions' programs, but no other the libraries that follow this model, either on an ad hoc basis or as a formal program, have published reports of these services. The literature includes several articles on rush acquisitions, most notably by Clendenning [4], but not in conjunction with rapid fulfillment of interlibrary loan requests.

Two Models for On-Demand Collection Development

This paper explores the on-demand collection development partnerships between interlibrary loan and acquisitions at two research libraries, those at the University of Wisconsin-Madison and at Purdue 
University. It describes each program and then compares the similarities and differences. Both institutions are publicly supported research universities in the Midwest with similarly sized student enrollments. They are both members of the Committee on Institutional Cooperation (CIC) consortium, which includes reciprocal interlibrary loan agreements as well as other library-related initiatives.

\section{University of Wisconsin-Madison, Memorial Library}

The University of Wisconsin-Madison Libraries comprise collections in over 40 campus locations and serve a student population of 41,000 and a faculty and staff population of 19,000. Interlibrary loan activities are decentralized and are handled in seven major operations across the campus. Memorial Library is the principal research library on campus for the humanities and social sciences and handles the largest volume of interlibrary loan borrowing requests. In 2001/02, the Memorial Library interlibrary loan (borrowing) department handled 38,000 requests from UW-Madison patrons and filled 31,434 of them from off- 
campus sources. Five other interlibrary loan units on campus handled an additional 18,000 ILL borrowing requests and filled over 14,500 of them from offcampus sources. The total amount spent on print book purchases for the same year was $\$ 1.8$ million and over 80,000 new monographic volumes were added to the collections.

Early in 2000 the Director of UW-Madison's General Library System requested that the Memorial Library interlibrary loan department explore ways to acquire selected interlibrary loan titles rapidly. He was interested in the interaction between expressed patron needs (interlibrary loan) and collection development, and wanted to determine whether it would be advantageous to patrons and the collection to acquire some titles requested through Memorial Library's interlibrary loan service.

The Head of Public Services and the interlibrary loan staff developed criteria for determining when an item would be purchased. The criteria were approved by bibliographers and selectors and included:

- Items must be in scope for UW-Madison's General Library System. This excludes practical 
education materials, law, medicine, and American history; subject areas that are housed in libraries that are not managed by the GLS. (Note: The Wisconsin Historical Society Library resides on campus and is responsible for purchase of American history materials that support UW-Madison's teaching and research mission.)

- Published in the current year plus two previous years (later expanded to current plus three years)

- Monographs or proceedings (not textbooks or computer manuals).

- Maximum cost of $\$ 250$.

- Additional copies of potentially high use items may be purchased.

- Foreign language and imprint titles may be purchased.

Initially $\$ 2,000$ was allocated from the collections budget to acquire titles in this project. In the second year, $\$ 3,000$ was allocated. Given the budget constraints of the project, interlibrary loan 
requests were first sent to other libraries as borrowing requests. After five libraries could not fill a request, the Head of the Interlibrary Loan Department used the selection criteria to determine if the title was a candidate for purchase. Interlibrary loan and acquisitions staff developed procedures and workflows that brought selected interlibrary loan requests into a rush acquisitions workflow. Acquisitions and cataloging staff process orders generated from interlibrary loan requests using rush procedures that were retooled in February 2000 for all patron-initiated orders. Key to deciding when an item will be rush acquired is determining the actual date that a patron needs the item. Patrons indicate on order requests and interlibrary loan requests a date by which they need the item. Staff make every attempt to acquire or borrow the item by that date. If a 'needed by' date is not provided, the acquisitions department assumes that the item is needed within two weeks. During the first two years of this project, webbased acquisitions sources or local bookstores were preferred for rush purchases. Multiple sources were contacted to determine availability and, whenever 
possible, an institutional credit card was used to facilitate rapid payment and delivery. At the time of writing, the preferred sources were: Amazon.com ${ }^{\circledR}$ and bn.com (Barnes \& Noble) depending on which online provider offered the best discount and least expensive shipping rate. If unavailable from these two sources, staff contact the publisher or distributor. If the title is out of print, the order staff contact online out of print sources. Vendors are rarely used for domestic imprints; however, they are consulted for foreign purchases. Often it is far easier to acquire a foreign item from a vendor than to go directly to the publisher.

The general process is:

\section{Interlibrary Loan:}

- Interlibrary Loan attempts to borrow a book. Five potential lenders fail to loan the book.

- If the title meets purchase criteria, the Head of Interlibrary Loan assigns the campus library that will house the title, based on the title and content information. 
- A note indicating referral to acquisitions is keyed into the Custom Search field in the unfilled request in the Clio ILL management system.

- The Interlibrary Loan Department forwards a printout of the ocLC interlibrary loan request to the Acquisitions department.

\section{Acquisitions and Cataloging:}

- If the title is already expected via an approval plan but is not yet shipped, acquisitions staff 'block' the approval order in the vendor system. If the title has already been shipped through an approval plan, order staff create an order for the item and indicate that it should be rush processed when received.

- If the title is not arriving via an approval plan, acquisitions staff determine availability at the preferred rush order sources. 
- If staff determines that the title is unavailable, the request is returned to interlibrary loan.

- Acquisitions staff place the rush order:

- Orders are placed against the interlibrary loan (ILL) fund within the acquisitions module of the UW-Madison integrated library system.

- Shipping costs over $\$ 15$ require approval by the Chief Acquisitions Librarian.

- The Patron ID, name, and patron-requested pickup library are input in the order notes field.

- The order is claimed in fourteen days if not received.

- Titles that are on order are viewable in the online catalog.

- At the point of receipt, the patron ID and name are removed from the acquisitions order record.

- The item is rush cataloged and processed.

- If the title is not received in three weeks, acquisitions and interlibrary loan staff discuss whether the item should be borrowed or purchased.

\section{Circulation:}


- The item is delivered to the pickup library circulation desk.

- The circulation desk staff notify the patron of the book's availability. The patron borrows the book.

- When the book is returned, it is shelved, as it requires no additional processing. In the first two years of this project, 135 titles were purchased for $\$ 4,976$ (including shipping). The average cost to acquire the titles was $\$ 36.86$, including an average shipping cost of only $\$ 3.85$. Generally, the breakdown by patron status reflected the normal ILL pattern: $48 \%$ purchased in response to graduate student requests, 9\% for undergraduates, and 43\% for faculty and staff. Titles were primarily domestic imprints (108 titles, or $80 \%$ ), although a significant portion were foreign (27 titles, or 20\%).

For 2001/02, the breakdown of filled Interlibrary Loan requests was $71 \%$ loans (returnables) and 29\% copies (non-returnables), a typical distribution for Memorial Library. The Memorial Library loans figure includes the on-demand titles. Of all ILL loan (returnables) activity, only $0.3 \%$ were on-demand titles. 


\author{
Handling these requests through the rush \\ acquisitions and cataloging processes proved to be \\ very effective for domestic imprints, with most titles \\ being available for patron pickup after only eight \\ calendar days on average. This turnaround time was \\ very close to the average of ten calendar days for an \\ average loan to arrive at Memorial Library \\ interlibrary loan. Foreign imprints took on average \\ one month to arrive and be made available to the \\ patron. Many of the purchased foreign titles had been \\ deemed 'unborrowable' through interlibrary loan. The \\ fact that the library was able to provided these \\ otherwise unobtainable titles was considered to be \\ good patron service. Table 1 lists the six major \\ sources that UW-Madison used to acquire the 135 on- \\ demand items. \\ Circulation data for titles purchased on the ILL \\ fund were analyzed in comparison to items purchased \\ for the Memorial Library stacks during the same two- \\ year period. This analysis provided insight into the \\ use of the on-demand titles by other patrons after the \\ first use. Titles were in the Endeavor Voyager system \\ at the time of the first use by the interlibrary loan \\ requestor.
}


At the end of the project's first 24 months, the 135 items circulated an average of 3.5 times each, and 73\% of the items had circulated two or more times. In contrast, $6 \%$ of the items purchased for the Memorial Library general collection during the same 24 months circulated two or more times. A query in the local Endeavor Voyager integrated library system database was run against items in the Memorial Library stacks, the location for which the majority of the on-demand books are cataloged, to determine this percentage. When reviewing the above data, one must remember that the selection criteria for the two groups of books are not identical. The on-demand titles meet the immediate short-term needs of patrons, while the regularly purchased titles are being selected for posterity. This is not to suggest that most of the books purchased through the on-demand service would not also meet the same high standards of those being purchased for long-term use.

In February 2002 the books on demand project at the University of Wisconsin-Madison was deemed a success and taken out of pilot status. The project was expanded in september 2002 with the allocation of $\$ 20,000$ in gift funds toward what is now called 'Book 
Express.' Rather than waiting to determine if five lending libraries will provide a title via interlibrary loan, in scope titles are immediately sent to acquisitions for purchase. The selection criteria were also expanded to include the current year imprint plus four years.

Staff insert a bookmark into all items purchased through Book Express to query patrons about the service. After a year of tracking the titles purchased via Book Express, interlibrary loan and acquisitions staff will review patron responses to see if the service needs any adjustments. Book Express orders will be coded to track whose requests generate the most numbers of acquisitions: undergraduates, graduates, or faculty/staff. Moreover, a bibliographers' analysis of the titles ordered through Book Express will be completed to determine if these titles meet the same standards for selection for other titles.

\section{Purdue University Libraries}

Located in West Lafayette, Indiana, Purdue University serves a student population of 38,000. The 
Libraries comprise 14 collection locations and a storage facility. In 2001/02, the centralized interlibrary loan unit received 50,912 requests from Purdue patrons and filled 29,503 of them from offcampus sources (the vast majority of the remaining 21,409 requests were for items available on campus). The total monograph budget for the same year was one million dollars and 16,000 books were added to the Libraries collections.

In 1999, the Access Services Librarian, who supervises the interlibrary loan unit, observed that many of the requests for book loans were for recently published scholarly titles. These books were widely held by other research libraries and appeared to be good candidates for inclusion in the local collection. She analyzed the prior six months of book loan data, and then approached the Public Services Advisory Committee, led by the Associate Director for Public Services and Collections and including the Head of Technical Services, with a proposal for a pilot project. She suggested that the group review suggested guidelines that ILL staff might follow to purchase requested titles from a rapid delivery Internet bookseller. The books would be lent to 
patrons directly from ILL, and then forwarded to Technical Services for cataloging after patron use.

The public services group agreed to the following purchasing criteria:

- scholarly works in English

- published within the past five years

- available for shipment within one week

- maximum cost of $\$ 100$ (later raised to \$150)

The online bookseller selected was Amazon.com ${ }^{\circledR}$, based on good performance during previous occasional use for rush orders and several librarians' positive personal experiences with this company.

The Associate Director for Public Services and Collections funded the Books on Demand pilot project with $\$ 15,000$ from non-recurring funds for an initial six-month period beginning in January 2000. Funding has been renewed each semester since then at a level sufficient to purchase all titles that meet the acquisitions criteria. The library assistant with responsibility for processing most ILL monographs 
requests used the guidelines for deciding whether book requests were eligible for purchase. The general process is as follows:

- Is the request for a scholarly book in English published within the past five years?

- If yes, is it available at Amazon.com ${ }^{\circledR}$ for $\$ 150$ or less and for shipment within one week?

- If yes, print two copies of the Amazon.com ${ }^{\circledR}$ page for the title, one for Technical Services and one for ILL.

- Assign the home library for the book, based on the book's subject area and the requester's departmental affiliation.

- Take one Amazon. com $^{\circledR}$ printout to Technical Services, where Acquisitions staff place the order with Amazon. $\mathrm{Com}^{\circledR}$ and also enter an "on order" record into the online catalog.

- Enter the request into Clio, the ILL management program, using AZZ as the supplier code (a made-up three-letter code in OCLC location code format to facilitate tracking). 
- Upon receipt of the book (shipped directly to the ILL office), put a property stamp in the book and then process like any other ILL loan. Include a questionnaire bookmark for the patron.

- When the patron returns the book, keep the questionnaire bookmark for later analysis.

- Update ILL records.

- Insert a flag into the book to alert Technical Services and the home library that it is part of the Books on Demand project.

- Forward the book to Technical Services for cataloging

This workflow meets the library's internal needs in that it requires minimal extra work for ILL staff and minimal pre-processing work by Technical Services staff. There is no rush handling, a practical impossibility for a program that generated almost 2,000 book purchases during its first 30 months of operation

For 2001/02, the breakdown of filled Interlibrary Loan requests was $69 \%$ copies (non-returnables) and $31 \%$ 
loans (returnables). The loans figure includes the on-demand titles. Of all loans, 12\% were on-demand titles.

Evaluating the project is an important part of managing it, since administrators use evaluation data to make funding decisions. The four evaluation areas were:

- patron departments and status data

- subsequent circulation data

- patron feedback

- bibliographers' analysis

For the first three evaluation criteria, the Access Services Librarian provided information periodically to the Libraries administration. She compiled patron data from the Clio ILL management software. Generally, the breakdown by patron status reflected the normal ILL pattern of 36\% for faculty/staff, 52\% for graduate students, and 12\% for undergraduates. Early fears that a few patrons would receive most of the books proved unfounded. After 30 
months, 1,943 books had been provided to 810 different patrons. Over half of the patrons (457) only received one book each. At the other end of the spectrum, one patron received 28 books, another 24 books, and a third 20 books, but the vast majority (82\%) of the patrons each received three or fewer books. The average was 2.4 books per patron. The average book costs $\$ 37.50$, including shipping charges.

The Access Services Librarian obtained subsequent circulation data by running a query in the local Endeavor Voyager database for the Books on Demand fund and for those funds that serve the Humanities, Social Sciences and Education (HSSE) Library, the location for which the majority of the on-demand books are cataloged. Over 30 months, 57\% of the on-demand titles subsequently circulated at least once (after they were cataloged following their initial ILL circulation) compared with at least one circulation for 31\% of HSSE Library books routinely acquired during the same period. The results of another query show that of the 532 Books on Demand titles acquired between January 1 and June 30, 2002 circulated 502 times, or .9 times per book (after the initial circulation through Interlibrary Loan) by December 31, 
2002. The 1,663 HSSE Library books acquired during the same time period circulated 718 times, or .4 times per book by the same date. These results should be viewed conservatively, however, since the selection criteria for the two groups of books are not identical.

Patron feedback data came from compiling responses to the short questionnaire on the bookmarks distributed with each on-demand book. Almost all of the 61\% of patrons who responded said that their books arrived in time; other data show the average turnaround time for on-demand books is the same as for normally borrowed books (eight days). The questionnaire also asked how useful patrons thought the books would be for the Libraries' collections: 76\% replied "very useful"; 20\% responded "moderately useful"; and only 4\% indicated "marginally useful." Patron comments were also almost unanimously positive. The final evaluation criteria involved bibliographers' participation in a detailed analysis project. Table 2 shows the number of on-demand books acquired during the project's first two years by patrons' academic department affiliations. 
From a total of 1,447 books, the titles in the disciplines in Table 2 represent 45\% (652 titles). There were also another 196 requests from students with no departmental affiliation; many of these books fell into one of these subject areas, so in the course of their analysis the bibliographers reviewed at least half of the total number of on-demand books.

The bibliographers' charge was to:

- analyze the Books on Demand titles in their subject areas;

- compare the on-demand titles with similar books acquired through normal collection development during the same time period;

- consider the options for refining approval plans to include material similar to the on-demand titles; and

- make recommendations for the future of the Books on Demand program.

A complete review of their findings is

forthcoming. [6] In summary, however, the bibliographers found that 80-99\% (depending on the 
discipline) of the on-demand titles were appropriate for the Libraries collection. They would have bought these books if requested to do so by a faculty member and/or if their collection development funds had been larger. They agreed that the on-demand program was a good way for graduate students to have a voice in developing the collection, and a cost-effective way to add potentially high-use titles. Many on-demand titles showed a distinct trend to cover some interdisciplinary subject areas that are sometimes under-funded in routine collection development. The bibliographers' unanimous conclusion was that ondemand acquisitions as a result of interlibrary loan book requests are a customer-centered, cost-effective, easy, and high-impact way to complement normal collection development.

As a side note, the project funding does not reduce the normal collections allocation as it is assigned from a separate budget. The funds provided to support the books on demand program, although generous, represent the equivalent of about 3\% of the annual monograph budget. This low percentage suggests that on the whole the traditional selection and acquisitions processes are effective in providing 
users with the majority of the books they need. The 700-800 titles added per year through the Books on Demand program generally represent some high-use (at least in the short term) material reflecting patron interests in interdisciplinary subjects, emerging topics, and very recently published works, as well as a few titles that are inevitably missed during routine collection development.

Conclusions and Future Directions

Over two years' experience with each of these programs confirms that on-demand book acquisitions is a viable model that meets the dual goal of filling a patron's immediate need for a recently published book and of adding a potentially high-use title to the collection. The model blends the formerly disparate library functions of access and ownership. The concept works successfully in environments with a high level of funding (Purdue) or with a more modest budget (Wisconsin). Local workflows may involve a high level of Technical Services involvement (Wisconsin) or a minimal level (Purdue). Professional staff 
(Wisconsin) or support staff (Purdue) may make the purchase decisions based on local selection criteria. The program can use a single online bookseller (Purdue) or multiple suppliers (Wisconsin). Patrons may be aware of the program (Purdue) or not (Wisconsin). When they are aware, patrons report extremely high levels of satisfaction both with the turnaround time and with the quality of the titles acquired. At both institutions, subsequent circulation data suggest that at least in the short term patrons use the on-demand books more heavily than similar books purchased at the same time through routine collection development.

Subsequent analysis of purchased titles by Purdue subject bibliographers suggests that a Books on Demand program meets several needs: developing the collection based on patrons' (usually graduate students') expressed needs; serving as a "safety net" for acquiring titles that might otherwise be overlooked, especially in interdisciplinary areas; and collecting books with a guarantee of at least one use (probably more cost-effective than expanding approval plan profiles). Purdue bibliographers also determined that a very high percentage of on-demand titles were 
appropriate for the collection and that they would have ordered them if asked, or if their collection development funds had been larger.

This model appears to work especially well for titles in the social sciences and humanities. It is less clear whether the books-on-demand approach is as effective for acquiring titles in the sciences, technology, and engineering (STE). Both institutions found that STE titles made up a smaller percent of the total titles acquired $(20 \%$ at Purdue and $21 \%$ at Wisconsin). With high maximum cost caps at both institutions, book cost was not an issue. With the Purdue model, only Amazon. $\mathrm{com}^{\circledast}$ was used as a source so one factor in the low number of STE titles could be attributed to the fact that Amazon. $\mathrm{com}^{\circledast}$ generally could not ship these more specialized titles within the short time frame needed. STE titles in scope for the UW-Madison General Library System could be obtained through the multiple acquisitions sources used by UWMadison. However, it is also true that in general patrons request loans of STE titles much less frequently than they request loans of social sciences and humanities titles. 
UW-Madison's Memorial Library handles primarily humanities and social sciences interlibrary loan borrowing requests. It is not known whether the STE and medical titles handled by the other UW-Madison interlibrary loan offices would be as easily obtained as rush acquisitions. On-demand monographic purchases in STE subject areas may just be less necessary since those disciplines place a greater emphasis on the journal literature.

On-demand collection development programs need not be limited to academic libraries. Some public libraries report having on-demand programs [2], but they tend to be less formalized than the programs described here. Thomas Crane Public Library (Quincy, Massachusetts) has reported on a program in existence since 1998. [7] Thomas Crane Public Library reports results similar to those described here, including improved patron service, rapid title receipt and delivery to patrons, and high circulation of on-demand titles to subsequent patrons.

There are many variables in developing, implementing, and managing an on-demand book purchase program. A library interested in this concept can start as small or as large as funding permits, and can 
adjust almost all the factors (e.g., selection

criteria; number of potential suppliers; maximum cost;

workflow) to suit local needs and still provide an

innovative and successful patron service. 
$\underline{\text { References }}$

1. Jackson, M. E. (1998) Measuring the Performance of Interlibrary Loan Operations in North American

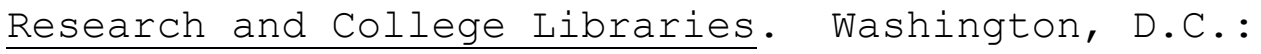
Association of Research Libraries, 21.

2. E-mail correspondence to Tanner Wray in response to a query to the ILL-L listserv in september 2001.

3. Perdue, J. and Van Fleet, J. A. (1999) "Borrow or Buy: Cost-Effective Delivery of Monographs." Journal of Interlibrary Loan, Document Delivery \& Information Supply, 9 (4), $19-28$.

4. Clendenning, L. F. (2001) "Purchase Express for Any User Request: the University of Virginia Library Offers Delivery in Seven Days." College \& Research Libraries News, 62 (1), 16-17.

5. Ward, S. M. (2002) "Books on Demand: Just-in-Time Acquisitions." The Acquisitions Librarian, (27), $95-107$ 
6. Anderson, K. J., Freeman, R. S., Hérubel, J.-P. V. M., Mykytiuk, L. J., Nixon, J. M., and Ward, S. M. "Buy, Don't Borrow: Bibliographers' Analysis of Academic Library Collection Development through Interlibrary Loan Requests." Collection Management, 27 (3), forthcoming.

7. Allen, M., Ward, S. M., Wray, T., and Debus-López, K. E. (2003) "Patron-Focused Services: Cooperative Interlibrary Loan, Collection Development and Acquisitions." Interlending \& Document Supply, 30 (2), forthcoming. 
Table 1. Number of On-Demand Books by Supplier, UWMadison, May 2000-April 2002

\begin{tabular}{|l|c|c|}
\hline Supplier & $\begin{array}{l}\text { No. } \\
\text { Acquired }\end{array}$ & $\begin{array}{l}\text { \% } \\
\text { Total }\end{array}$ \\
\hline $\begin{array}{l}\text { Amazon.com (includes } \\
\text { Amazon.com's UK and France } \\
\text { sites) }\end{array}$ & 57 & $42 \%$ \\
\hline $\begin{array}{l}\text { Borders bookstore (no longer } \\
\text { used) }\end{array}$ & 46 & $34 \%$ \\
\hline Barnes and Noble and bn.com & 14 & $10 \%$ \\
\hline $\begin{array}{l}\text { Foreign Vendor } \\
\text { Publisher }\end{array}$ & 10 & $8 \%$ \\
\hline Domestic Vendor & 3 & $2 \%$ \\
\hline \begin{tabular}{l} 
TOTAL \\
\hline
\end{tabular} & 135 & $100 \%$ \\
\hline
\end{tabular}

Table 2. On-Demand Books Acquired by Patron Department, Purdue University, 2000-2002

\begin{tabular}{|l|c|c|}
\hline Academic Department & No. Books & $\begin{array}{l}\text { \% of 1, 447 } \\
\text { total books }\end{array}$ \\
\hline & & \\
\hline English & 231 & $16 \%$ \\
\hline History & 138 & $10 \%$ \\
\hline $\begin{array}{l}\text { Foreign Languages \& } \\
\text { Literatures }\end{array}$ & 88 & $6 \%$ \\
\hline Political Science & 70 & $5 \%$ \\
\hline Management & 67 & $5 \%$ \\
\hline Philosophy & 58 & $4 \%$ \\
\hline & 652 & $45 \%$ \\
\hline
\end{tabular}

